В. М. Мацькевич, Д. Б. Соломчак ДВНЗ “Івано-Франківський національний медичний університет”

\title{
НАВЧАННЯ СТУДЕНТІВ МЕДИЧНОГО ФАКУЛЬТЕТУ КОНСТРУКТИВНОГО КРИТИЧНОГО АНАЛІЗУ ТЕКСТУ ПРИРОДНИЧИХ НАУК ІЗ ЗАСТОСУВАННЯМ ПЕДАГОГІЧНИХ “БОКСІВ”-ОПИТНИКІВ ТА МЕТОДИЧНИХ ВКАЗІВОК ДЛЯ ОБ’ЄКТИВНОЇ ОЦІНКИ ДОСТОВІРНОСТІ МАТЕРІАЛУ
}

\author{
V. M. Matskevych, D. B. Solomchak \\ Ivano-Frankivsk National Medical University \\ TEACHING OF CONSTRUCTIVE CRITICAL ANALYSIS OF THE \\ NATURAL SCIENCES' TEXT FOR STUDENTS OF THE MEDICAL \\ FACULTY WITH THE USING OF PEDAGOGICAL "BOXES” \\ -QUESTIONNAIRES AND GUIDANCE FOR THE OBJECTIVE \\ ASSESSMENT OF MATERIAL RELIABILITY
}

\begin{abstract}
Мета роботи - оцінювання навичок критичного мислення з подальшим розвитком конструктивного скептицизму у студентів медичного факультету із застосуванням допоміжних методичних розробок.

Основна частина. Вміння критично сприймати інформацію та керувати ії̈ потоком є потужним інструментом освіти, від якого залежить ефективність селекції емпірично цінного матеріалу від псевдонаукового. Вивчено різницю в сприйнятті матеріалу статті студентами залежно від тренінгу із спеціальними методичними рекомендаціями М. К. Ірібар та розробленим для третього курсу опитником на основі “боксів” J. Young, M. Solomon, T. Greenhalgh, U. Flick з авторськими корективами. Запропоновано проаналізувати прочитаний зміст тексту за п'ятьма показниками, такими, як: достовірність, наявність доказової бази, чіткість викладення, логічність взаємозв'язків та валідність статті. Встановлено, що, працюючи з вищевказаними матеріалами, на вихідному зрізі знань аналіз статей студентами медичного факультету суттєво відрізнявся порівняно з первинним оцінюванням. Аналізуючи отримані результати, можна стверджувати про необхідність освітніх тренінгів для осіб, які використовують у своїй діяльності надбання нових досліджень, зокрема, саме для уникнення псевдонаукових рекомендацій та впроваджень у практику.

Висновок. У студентів медичного факультету відзначаються позитивні статистично значимі зміни $(\mathrm{p} \leq 0,001)$ щодо критичного аналізу опрацьованого матеріалу на кінцевому зрізі знань після застосування методичних розробок для конструктивної оцінки наукових статей та опитника.
\end{abstract}

Ключові слова: критичне мислення; методичні вказівки; аналіз матеріалу; достовірність; доказова база.

The aim of the work - assessment of the skills of critical thinking with the further development of constructive skepticism in medical students with the use of adjuvant methodological development.

The main body. The ability to critically perceive information and control its flow is a powerful educational tool, which determines the effectiveness of selection of empirically valuable material from pseudoscientific. It is studied the difference in the perception of the article by the students, depending on the training with the special methodical recommendations of M. K. Iribar and questionnaire developed for the third course, based on "boxing” J. Young, M. Solomon, T. Greenhalgh, U. Flick with author's corrections. It is suggested to analyze the read content of the text in five indicators: reliability, availability of evidence base, clarity of presentation, logic of interrelations and validity of the article. It was established that the output level of knowledge of the article analysis by the medical students significantly differed from the initial assessment after working with the above-mentioned materials. Analyzing the results, it can be argued that educational training is needed for those who use in their work the objects of new research, in particular, precisely to avoid pseudoscientific recommendations and implementations into the practice.

Conclusions. Medical students show positive statistically significant changes $(\mathrm{p} \leq 0.001)$ regarding the critical analysis of the processed material on the final cut of knowledge after application of methodological recommendations and the questionnaire for the constructive assessment of scientific articles.

Key words: critical thinking; methodological recommendations; material analysis; reliability; evidence base. 
Вступ. Критичне читання - це високодоступна навичка, важлива для опрацювання професійних академічних текстів, розпізнавання наукового дискурсу, як двостороннього конструктивно-аналітичного процесу, в якому завжди присутні двоє: автор статті та читач [1]. Ефективність сприйняття інформації та керування її потоком $€$ потужним інструментом освіти, тому ціннісним $є$ вибір максимально необхідних для аналізу догм із подальшим поглибленим вивченням, застосовуючи для вирішення кожної конкретної проблеми. Поруч із сприйняттям рівнозначною є критична оцінка тексту, відкидання зайвої інформації, а також вміння розпізнавати неправдиві бездоказові повідомлення. Завданням студента природничих наук $є$ навчитись ідентифікувати сильні та слабкі сторони статті науково-технічного характеру з визначенням якості і користі опрацьованих даних [2].

Мета роботи - оцінювання навичок критичного мислення з подальшим розвитком конструктивного скептицизму у студентів медичного факультету із застосуванням допоміжних методичних розробок.

Основна частина. У період 2016-2017 років у дослідженні взяли участь 80 студентів третього та четвертого курсів медичного факультету з українською мовою навчання. Усі особи підписали інформовану згоду щодо ознайомлення та узгодження опрацювання отриманих даних на підставі конфіденційної обробки інформації. Імена учасників було закодовано для об’єктивізації оцінювання відповідей. Матеріали статей для вивчення надавались електронно для полегшення учасникам роботи над посиланнями до статей, що входило в завдання дослідження (50 \% у форматі цифрового ідентифікатора об'єкта (doi); 50 \% у вигляді протоколу передачі гіпертекстових документів (http) без присвоєння сталого цифрового ідентифікатора зразка інтелектуальної власності). Спочатку одразу після прочитання статті студентам пропонувалось у довільній формі описати власну думку щодо вірогідності даного матеріалу. Потім усі учасники ознайомились із принципами ієрархії доказів у наукових публікаціях та отримали опитник для заповнення у паперовому вигляді, який сформовано на базі “боксу” Дж. М. Янг та М. Дж. Соломона, Т. Грінхалф, У. Фліка [2-4] з поправкою на теоретичні та практичні знання студентів третього курсу (додаток 1). Після роботи з методичними вказівками, розробленими Марією К. Ірібар [5] по аналітичному читанню, учасники повторно письмово надавали короткий власний критичний огляд опрацьованого матеріалу з оцінюванням п’ятьох показників: достовірності, наявності доказової бази, чіткості викладення, логічності взаємозв’язків та валідності статті. Для статистичного аналізу використовували t-критерій Стьюдента для залежних вибірок (нормальний розподіл величин).

Еквівалентна оцінка вхідного та вихідного рівнів знань відзначена лиш у 6 студентів (7,5 \%), тобто вони змогли адекватно критично сприйняти запропонований матеріал, як до тренінгу з методичними вказівками, так і після нього. Решта 74 особи (92,5 \%) у початковому анкетуванні значно завищили якість прочитаних статей, вказавши у 67 випадках (83,75 \%), що матеріал достовірний, логічно викладений та містить доказову базу. При роботі з методичними вказівками та опитником на вихідному зрізі знань аналіз статей студентами суттєво відрізнявся. Нульовою гіпотезою у даному дослідженні $є$ твердження про відсутність відмінностей між середніми значеннями до та після опрацювання методичних вказівок та опитника. Відповідно, альтернативною гіпотезою $€$ достовірність зміни між показниками на початковому та кінцевому зрізах знань. Середнє значення ознаки до експерименту склало 1,163 (SD 0,154), після експерименту 4,388 (SD 0,131). Число ступенів свободи (f) становило 79. Парний t-критерій Стьюдента 18,486. Критичне значення t-критерію Стьюдента при даному числі ступенів свободи склало 1,991. $\mathrm{t}_{\text {емп }}>\mathrm{t}_{\text {крит }},(\mathrm{p} \leq 0,001)$, що дозволяє відхилити нульову гіпотезу про відсутність різниці, а зміни ознаки є статистично значимі.

Аналізуючи отримані результати, можна стверджувати про необхідність тренінгів для осіб, які використовують у своїй діяльності надбання нових досліджень, зокрема, саме для уникнення псевдонаукових рекомендацій та впроваджень. Потрібно звертати увагу на наявність рецензії статті експертом з даної галузі, а не просто опубліковане повідомлення в ЗМІ без проведення жодної редакційної оцінки матеріалу. Також слід зауважити кількість самоцитувань, перевагою яких є поглиблене тривале вивчення даного питання, а недоліком - слабка доказовість компетентності та відсутність перевірки іншими вченими.

Треба звернути увагу, якщо в автора наявність лише іншомовних статей, виданих у журналах, які практикують переважно використання державної мови, де рівень рецензування, у зв'язку з недосконалим володінням застосованої у статті мови, може бути недостатнім. Бажано перевірити інформацію про автора по відкритих ресурсах, таких, як Scopus, The Web of Science Core Collection, які вказують індекс цитованості авторів. Також можна перевірити 
рейтинг журналів за допомогою підрахунку імпактфактора, щоб визначити значущість впливу певного видання на науковий розвиток предметної галузі.

Ще одним важливим нюансом є наявність академічної недоброчесності видань, які, маскуючись науковими журналами, видають статті, що $€$ рекламним проектом певних фармкомпаній [6]. Відповідальність вчених за оприлюднені результати значно зросте після того, як, згідно з проектом загальноєвропейської ініціативи Innovation Principle, прийнятим 27 травня 2016 року, за підтримки Коаліції наукових видань та академічних ресурсів (SPARC), усі публікації досліджень, проведених за державним замовленням, повинні бути викладені в депозитарії з відкритим безкоштовним доступом, що дозволить більшій кількості вузькогалузевих фахівців оцінити вказані результати, а також при потребі відтворити описане дослідження [7]. Зворотною стороною медалі даного рішення є, за повідомленням словацьких вчених М. Форманека та М. Заборського, слабкий захист персональних даних авторів від кібератак, які дослідники оцінили як поганий (рівень F), що потребує забезпечення належної технічної підтримки [8].

Одним із пунктів в оцінці актуальності інформаційного матеріалу є давність публікації. У цифрових бібліотеках є можливість пошуку статей необхідної проблематики відповідно до років видання та оновлень і доповнень вже існуючих досліджень тими ж авторами. Незважаючи на це, нехтувати старими публікаціями не варто, оскільки багато грунтовних важливих досліджень часто залишаються актуальними, остаточно доведеними, правильними та такими, що не потребують спростувань чи витрат на повторне вивчення.

Окремо слід звернути увагу на існування так званої “сірої літератури”, яка не має комерційного характеру, а подається у вигляді звітів, патентів, технічних документів, що часто видаються малим тиражем та не є обов'язковими в електронному вигляді. 3 появою цифрових репозитаріїв інформація “сірої літератури” часто ненавмисно ігнорується дослідниками, у зв’язку з складнішим її пошуком та меншим розповсюдженням. Хоча в жодному разі не можна применшувати їі цінність, оскільки ціллю такого виду інформації є їі констатація, моніторинг та збереження, а не суспільна популяризація. Проблемою важкодоступності “сірої літератури” займаються зараз усі провідні цифрові бібліотеки, зокрема у Фінляндії розробляють та удосконалюють дизайн цифрового бібліотечного сервісу з максимальним охопленням усіх видів публікацій [9].

Недоліком дослідження була неможливість оцінити в студентів третього та четвертого років навчання роботу зі статистичним аналізом у пропонованих статтях, оскільки заняття з біостатистики проводяться на старших курсах, тому це питання залишається в перспективі дослідження.

Висновок. У студентів медичного факультету відзначаються позитивні статистично значимі зміни ( $\leq \leq 0,001)$ щодо критичного аналізу опрацьованого матеріалу на кінцевому зрізі знань після застосування методичних розробок для конструктивної оцінки наукових статей та опитника.

\section{Опитник}

Додаток 1

\section{(на основі “боксів” J. Young, M. Solomon, \\ T. Greenhalgh, U. Flick 3 авторськими корективами)}

1. Чи відповідають висновки дослідження поставленим завданням?

2. Чи структура статті $є$ чітко структурованою, а не просто описовий довільний характер викладу думок?

3. Чи отримана інформація у статті є релевантною?

4. Чи об’єм вибірки був таким, отримані результати якого можна екстраполювати на генеральну сукупність?

5. Чи в описі передумов та обговоренні є посилання на актуальні дослідження інших вчених?

6. Чи дійсно в посиланнях списку літератури йде мова про вказану автором статті інформацію?

7. Чи є самоцитування у списку використаних джерел і скільки їх відносно цитувань інших дослідників?

8. Чи розглядає автор статті альтернативні твердження інших вчених, які суперечать отриманим результатам власного дослідження?

9. Чи методи і матеріали у статті описано настільки чітко, що дає можливість його відтворити для перевірки істинності результатів?

10. Чи у результатах дослідження наведені результати статистичної обробки, а не лише слова “більше”, “менше”, “краще”, “гірше” та ін.

11. Чи вказано практичну користь експерименту, галузь для його впровадження та можливі перспективні напрямки у роботі над даною проблемою?

12. Чи посилання на дослідження інших вчених $€$ у використаних джерелах, з яких можна отримати повну авторську інформацію?

13. Чи є слабкі сторони у дослідженні і чи сам автор дослідження критично вказує на них? 


\section{Список літератури}

1. Wallas M. Critical reading and writing for postgraduates / M. Wallas, A. Wray. - 3-rd ed. - London : SAGE, 2016. - 276 p.

2. Young J. M. How to critically appraise an article [Electronic resource] / J. M. Young, M. J. Solomon // Nature Clinical Practice Gastroenterology \& Hepatology. - 2009. No. 6 (2). - P. 82-91. - Mode access : http://doi.org/10.1038/ ncpgasthep1331.

3. Greenhalgh T. How to read a paper: the basics of evidence-based medicine / T. Greenhalgh. - 5-th ed. - Oxford : John Wiley \& Sons, Apr 2014. - 284 p.

4. Flick U. Introducing research methodology A beginners' guide to doing a research project / U. Flick. 2-nd ed. - London, England : SAGE, Mar 2015. - 320 p.

5. Викладання та навчання навичкам наукової роботи протягом переддипломної освіти : навч. посіб. / Х. М. Пейнадо, Ф. І. Вулф, М. К. Ірібар, А. М. Райд. Сполучене Королівство : Університет Лідса, 2014. C. 54-64.

6. Brondz I. Analytical methods in the quality control of scientific publications part V: The fraud of pseudoscientists

\section{References}

1. Wallas, M., \& Wray, A. (2016). Critical reading and writing for postgraduates. London: 3-rd ed. SAGE.

2. Young, J.M., \& Solomon, M.J. (2009). How to critically appraise an article. Nature Clinical Practice Gastroenterology \& Hepatology, 6 (2), 82-91. Retrieved from: http://doi. org/10.1038/ncpgasthep1331.

3. Greenhalgh, T. (2014). How to read a paper: The basics of evidence-based medicine. Oxford: John Wiley \& Sons, 5-th ed.

4. Flick, U. (2015). Introducing research methodology - A beginners' guide to doing a research project. London, England: SAGE, 2-nd ed.

5. Peinado, Kh. M., Vulf, F.I., Iribar, M.K., \& Raid, A.M. (2014). Vykladannia ta navchannia navychkam naukovoi roboty protiahom pereddyplomnoii osvity [Teaching and learning research skills at the undergraduate level]. United Kingdom: University of Leeds [in Ukrainian]. based on false measurements and method development [Electronic resource] / I. Brondz // International Journal of Analytical Mass Spectrometry and Chromatography. 2015. - No. 3. - P. 25-31. - Mode access : http://dx.doi. org/10.4236/ijamsc.2015.32003.

7. Ayris P. The importance of European collaborations of support Open Science and digital library development. [Electronic resource] / P. Ayris // LIBER Quarterly. - 2017. No. 26 (4). - P. 244-259. - Mode access : http://doi. org/10.18352/lq.10147.

8. Formanek M. Web interface security vulnerabilities of European Academic Repositories [Electronic resource] / M. Formanek, M. Zaborsky // LIBER Quarterly. - 2017. No. 27 (1). - P. 45-57. - Mode access : http://doi.org/10/18352/ lq.10178.

9. Kautonen H. Conceptualising benefits of user-centred design for digital library services [Electronic resource] / H. Kautonen, M. Nieminen // LIBER Quarterly. - 2018. No. 28 (1). - P. 1-34. - Mode access : http://doi. org/10.18352/lq.10231.

6. Brondz, I. (2015). Analytical methods in the quality control of scientific publications part V: The fraud of pseudoscientists based on false measurements and method development. International Journal of Analytical Mass Spectrometry and Chromatography, 3, 25-31. Retrieved from: http://dx.doi.org/10.4236/ijamsc.2015.32003.

7. Ayris, P. (2017). The importance of European collaborations of support open science and digital library development. LIBER Quarterly, 26 (4), 244-259. Retrieved from: http://doi.org/10.18352/lq.10147.

8. Formanek, M., \& Zaborsky, M. (2017). Web Interface Security Vulnerabilities of European Academic Repositories. LIBER Quarterly, 27 (1), 45-57. Retrieved from: http://doi. org/10/18352/lq.10178.

9. Kautonen, H., \& Nieminen, M. (2018). Conceptualising benefits of user-centred design for digital library services. LIBER Quarterly, 28 (1), 1-34. Retrieved from: http://doi. org/10.18352/lq.10231. 